\title{
Corrigendum: The burgeoning family of unconventional T cells
}

Dale I Godfrey, Adam P Uldrich, James McCluskey, Jamie Rossjohn \& D Branch Moody

Nat. Immunol. 16, 1114-1123 (2015); published online 20 October 2015; corrected after print 13 November 2015

In the version of this article initially published, the vertical axes of Figure 4 were labeled incorrectly as "(per $1 \times 10^{5} \mathrm{~T}$ cells)." The correct label is "(per $1 \times 10^{6}$ T cells)." These errors have been corrected for the PDF and HTML versions of this article.

Corrigendum: Eosinophils orchestrate cancer rejection by normalizing tumor vessels and enhancing infiltration of $\mathrm{CD}^{+} \mathrm{T}$ cells

Rafael Carretero, Ibrahim M Sektioglu, Natalio Garbi, Oscar C Salgado, Philipp Beckhove \& Günter J Hämmerling Nat. Immunol. 16, 609-617 (2015); published online 27 April 2015; corrected online 21 May and 13 November 2015

In the version of this article initially published, the graph in Figure 2e was incorrect. This has been replaced with the correct graph. The error has been corrected in the HTML and PDF versions of the article.

\section{Erratum: Group 3 innate lymphoid cells continuously require the transcription factor GATA-3 after commitment}

Chao Zhong, Kairong Cui, Christoph Wilhelm, Gangqing Hu, Kairui Mao, Yasmine Belkaid, Keji Zhao \& Jinfang Zhu Nat. Immunol.; doi:10.1038/ni3318; corrected online 8 December 2015

In the version of this article initially published online, in the third and fourth paragraphs of the Discussion section, the mice are incorrectly identified as $\operatorname{Rorc}^{\mathrm{gfb} /+}$. The correct genotype is Rorc ${ }^{\mathrm{gfp} /+}$. The error has been corrected for the print, PDF and HTML versions of this article. 